\title{
Activities of Ten Essential Oils towards Propionibacterium acnes and PC-3, A-549 and MCF-7 Cancer Cells
}

\author{
Yuangang Zu ${ }^{1,2, \uparrow}$, Huimin $\mathrm{Yu}^{3, \dagger}$, Lu Liang ${ }^{1,2}$, Yujie Fu ${ }^{1,2, *}$, Thomas Efferth ${ }^{4}$, Xia Liu ${ }^{1,2}$ and \\ Nan Wu ${ }^{1,2}$
}

1 Key Laboratory of Forest Plant Ecology, Ministry of Education, Northeast Forestry University, Harbin 150040, China; E-Mails: zygorl@vip.hl.cn (Y.Z.); luliang20100224@yahoo.com.cn (L.L.); 1x20030135@yahoo.com.cn (X.L.); bao_doubao@yahoo.com.cn (N.W.)

2 Engineering Research Center of Forest Bio-preparation, Ministry of Education, Northeast Forestry University, Harbin 150040, China

3 Chinese Medicine Department, The Second Hospital of Harbin Medical University, Harbin 150086, China; E-Mail: huimin1973@126.com (H.Y.)

4 Department of Pharmaceutical Biology, Institute of Pharmacy, University of Mainz, 55099 Mainz, Germany; E-Mail: t.efferth@dkfz.de (T.E.)

$\dagger$ These authors contributed equally to this work.

* Author to whom correspondence should be addressed; E-Mail: yujie_fu2002@yahoo.com; Fax: +86-451-82190535.

Received: 25 February 2010; in revised form: 20 April 2010 / Accepted: 20 April 2010 / Published: 30 April 2010

\begin{abstract}
Ten essential oils, namely, mint (Mentha spicata L., Lamiaceae), ginger (Zingiber officinale Rosc., Zingiberaceae), lemon (Citrus limon Burm.f., Rutaceae), grapefruit (Citrus paradisi Macf., Rutaceae), jasmine (Jasminum grandiflora L., Oleaceae), lavender (Mill., Lamiaceae), chamomile (Matricaria chamomilla L., Compositae), thyme (Thymus vulgaris L., Lamiaceae), rose (Rosa damascena Mill., Rosaceae) and cinnamon (Cinnamomum zeylanicum N. Lauraceae) were tested for their antibacterial activities towards Propionibacterium acnes and in vitro toxicology against three human cancer cell lines. Thyme, cinnamon and rose essential oils exhibited the best antibacterial activities towards $P$. acnes, with inhibition diameters of $40 \pm 1.2 \mathrm{~mm}, 33.5 \pm$ $1.5 \mathrm{~mm}$ and $16.5 \pm 0.7 \mathrm{~mm}$, and minimal inhibitory concentrations of $0.016 \%(\mathrm{v} / \mathrm{v})$, $0.016 \%(\mathrm{v} / \mathrm{v})$ and $0.031 \%(\mathrm{v} / \mathrm{v})$, respectively. Time-kill dynamic procedures showed that
\end{abstract}


thyme, cinnamon, rose, and lavender essential oils exhibited the strongest bactericidal activities at a concentration of $0.25 \%(\mathrm{v} / \mathrm{v})$, and $P$. acnes was completely killed after $5 \mathrm{~min}$. The thyme essential oil exhibited the strongest cytotoxicity towards three human cancer cells. Its inhibition concentration 50\% ( $\mathrm{IC}_{50}$ ) values on PC-3, A549 and MCF-7 tumor cell lines were $0.010 \%(\mathrm{v} / \mathrm{v}), 0.011 \%(\mathrm{v} / \mathrm{v})$ and $0.030 \%(\mathrm{v} / \mathrm{v})$, respectively. The cytotoxicity of 10 essential oils on human prostate carcinoma cell (PC-3) was significantly stronger than on human lung carcinoma (A549) and human breast cancer (MCF-7) cell lines.

Keywords: essential oils; activities; Propionibacterium acnes; cytotoxicity; cancer cell lines

\section{Introduction}

During recent years, plant essential oils have come more into the focus of phytomedicine $[1,2]$. Their widespread use has raised the interest of scientists in basic research of essential oils. Especially, the anti-microbial and anti-oxidant activities of essential oils as well as their potential anti-cancer activity have been investigated in recent years $[3,4]$.

Acne is an inflammatory chronic disease, whose clinical presentation can range from a mild comedonal form to severe cystic acne of the face, chest, and back. Factors which contribute to the development of acne include hormonal imbalance, bacterial infection, stress, food, or cosmetic application [5]. Propionibacterium acnes is a Gram-positive, anaerobic microorganism, which has been most recognized as a key factor for the development of acne [6]. For many years antibiotics and hormones were usually applied to treat acne [7,8]. However, these agents are often accompanied by severe side effects and drug resistance $[9,10]$. Therefore, phytotherapeutic approaches with high antibacterial activity and without side effects have been extensively studied as an alternative. In this context, essential oils extracted from herbs have also been investigated for the treatment of acne [11].

Standard cancer chemotherapy is frequently compromised by the development of drug resistance and unwanted, partly life-threatening side effects. There is, therefore, an urgent need for novel treatment options with improved features. Interestingly many plant-derived compounds, i.e., paclitaxel, vinblastine, or vincristine, and semi-synthetic derivatives of natural products, i.e., etoposide and teniposide, are used as anti-cancer drugs. As pointed out recently, natural products from medicinal plants represent a fertile ground for the development of novel anticancer agents [12].

Interestingly essential oils from some herbs and spices possess both anti-bacterial and cancer chemopreventive activities [13]. In previous studies, 10 essential oils including mint, ginger, lemon, grapefruit, jasmine, lavender, chamomile, thyme, rose and cinnamon showed good pharmacological activity [14-20]. In the present study, the anti-bacterial activities of a panel of 10 essential oils towards $P$. acnes was investigated by the disc diffusion and broth dilution methods as well as detection of dynamic bactericidal processes. Furthermore, we analyzed the cytotoxicity of these 10 essential oils against the human cancer lines, A549, PC-3 and MCF-7, by means of the MTT $(3-(4,5)-$ dimethylthiazol-2-yl)-2,5-diphenyltetrazolium bromide) assay. 


\section{Results and Discussion}

\subsection{Anti-bacterial activity}

We first analyzed the anti-bacterial activities of essential oils towards $P$. acnes. The data obtained from the disc diffusion method indicated that thyme essential oil exhibited the strongest inhibitory activities. The inhibition zone diameter measured was $40.0 \pm 1.2 \mathrm{~mm}$. Cinnamon essential oil also possessed considerable antibacterial activity, and the inhibition diameter determined was $33.5 \pm 1.5 \mathrm{~mm}$. Jasmine essential oil exhibited the lowest inhibitory activity (Figure 1). The results of minimum inhibitory concentrations (MICs) revealed that the thyme, cinnamon and rose essential oils exhibited the best anti-bacterial activities towards $P$. acnes. The MIC values were $0.016 \%(\mathrm{v} / \mathrm{v}), 0.016 \%(\mathrm{v} / \mathrm{v})$ and $0.031 \%(\mathrm{v} / \mathrm{v})$, respectively (Table 1$)$. The anti-bacterial activity of jasmine essential oil was lower than that of other essential oils, and its minimum bactericidal concentration (MBC) was $0.5 \%(\mathrm{v} / \mathrm{v})$. The MBC values of all 10 essential oils were comparable to their corresponding MIC values (Table 1).

Figure 1. Inhibition diameters of 10 essential oils towards P. acnes.

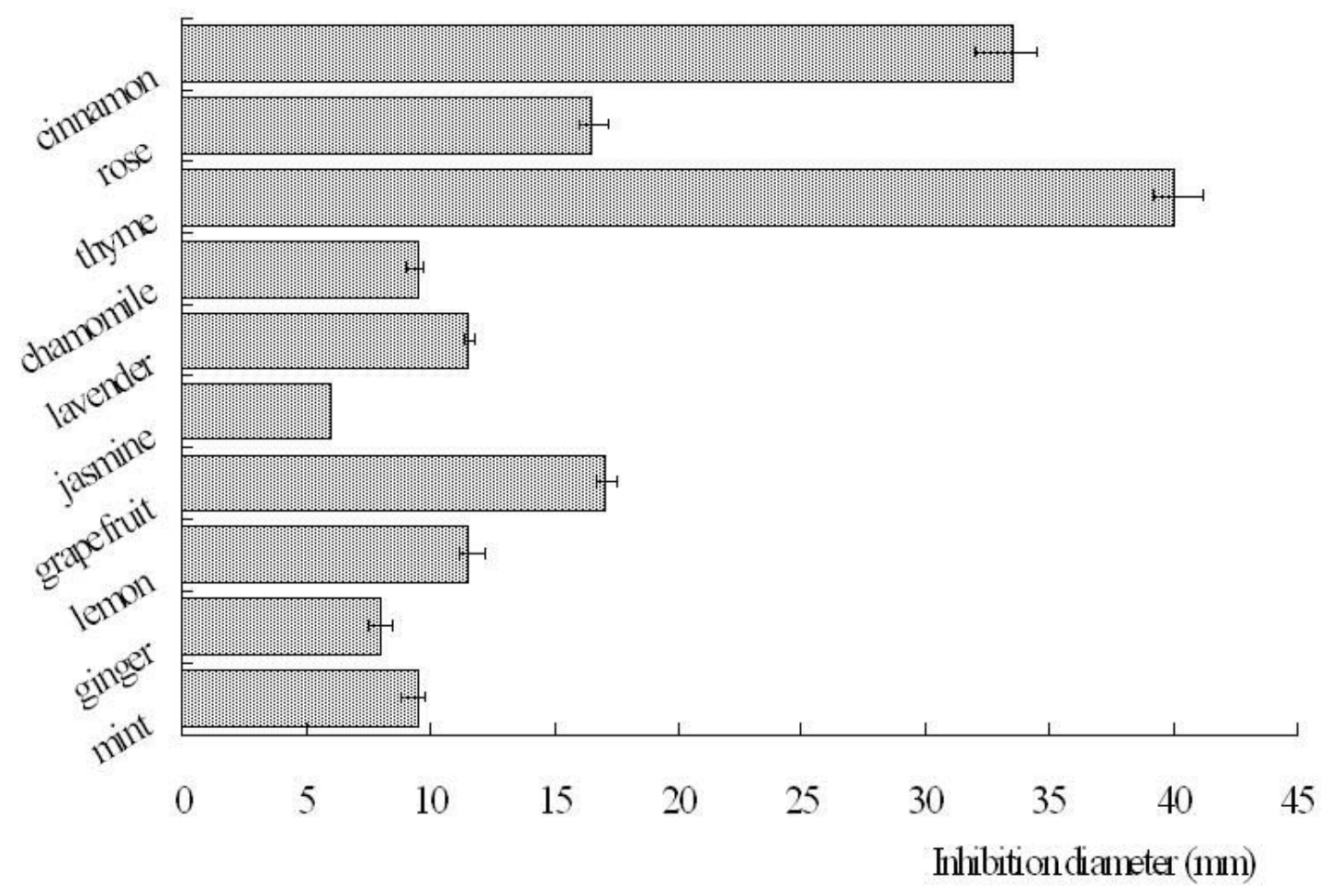

Table1. Minimal inhibitory concentrations (MICs, \%v/v) and minimal bactericidal concentrations (MBCs, \%v/v) of 10 essential oils towards P. acnes.

\begin{tabular}{ccccccccccc}
\hline & cinnamon & rose & thyme & chamomile & lavender & jasmine & grapefruit & lemon & ginger & mint \\
\hline MIC & 0.016 & 0.031 & 0.016 & 0.125 & 0.125 & 0.500 & 0.250 & 0.250 & 0.250 & 0.250 \\
MBC & 0.016 & 0.031 & 0.016 & 0.125 & 0.125 & 0.500 & 0.250 & 0.250 & 0.250 & 0.250 \\
\hline
\end{tabular}




\subsection{Time-kill curves}

The time-kill curves of the 10 essential oils are shown in Figure 2. Rose, cinnamon, thyme, and lavender essential oils exhibited the strongest bactericidal activities at a concentration of $0.25 \%(\mathrm{v} / \mathrm{v})$; the bacteria were completely killed within $5 \mathrm{~min}$. The bactericidal activities of the other essential oils decreased in the order: chamomile $>$ grapefruit $=$ lemon $>$ ginger $>$ mint $>$ jasmine. The bacteria were completely killed after $20 \mathrm{~min}$ by chamomile essential oil, $30 \mathrm{~min}$ by grapefruit and lemon essential oils, and $45 \mathrm{~min}$ by ginger essential oil. However, mint essential oil did not kill bacteria even after $120 \mathrm{~min}$. The jasmine essential oil exhibited the lowest bactericidal activity, and the number of P.acnes still retained $10^{5} \mathrm{CFU} / \mathrm{mL}$ after $120 \mathrm{~min}$.

Figure 2. Time-kill curves of 10 essential oils $(0.25 \% \mathrm{v} / \mathrm{v})$ towards P.acnes in $2 \mathrm{~h}$. (A): essential oils of mint, ginger, rose, cinnamon, and grapefruit; (B): essential oils of jasmine, lavender, chamomile, thyme, and lemon.
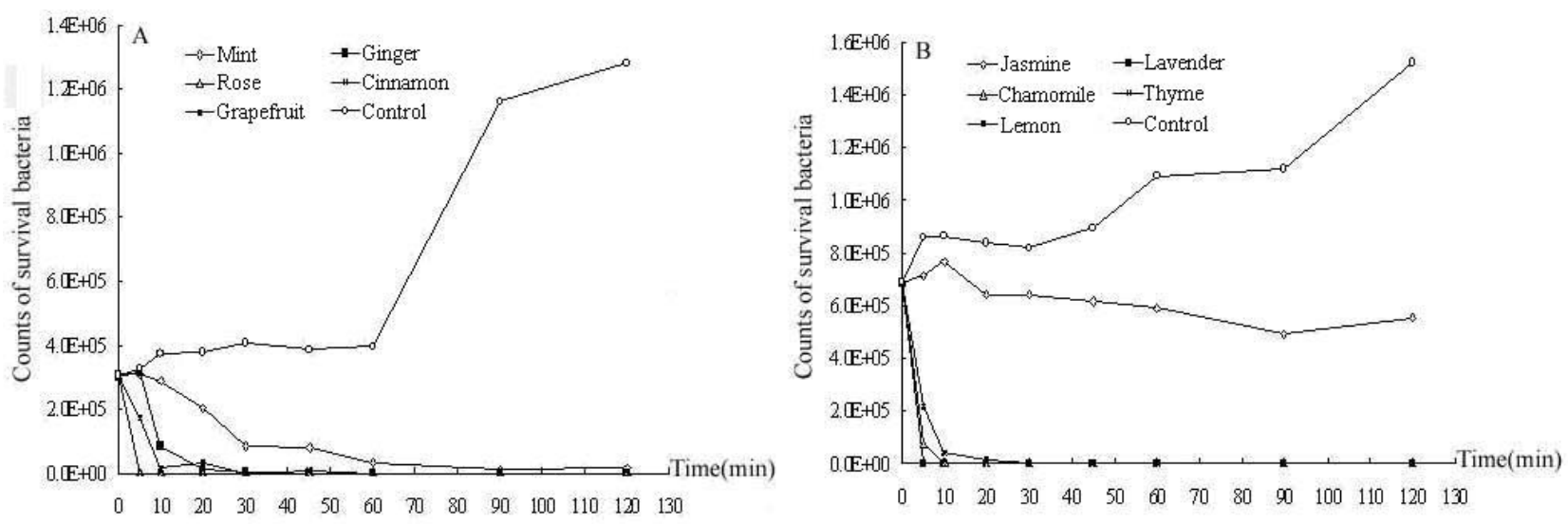

\subsection{Cytotoxic activity towards cancer cells}

To investigate the cytotoxic activities, three human tumor cell lines, A-549, PC- 3 and MCF-7, were exposed to increasing concentrations of essential oils. Cell viability was determined by the MTT assay. As shown in Figure 3 and Table 2 the essential oils revealed different cytotoxic activities towards the three human cancer cell lines investigated. In general, a dose-dependent decrease in the survival of the three tumor cell lines was observed. However, mint essential oil exhibited no effect on A549 cell over a concentration range of $0.002 \%$ to $0.2 \%(\mathrm{v} / \mathrm{v})$.

At a concentration of $0.002 \%(\mathrm{v} / \mathrm{v})$, the essential oils did not considerably affect the viability of the three human tumor cell lines compared with untreated control cells. The cell survival after treatment with essential oils was more than $80 \%$.

At a concentration of $0.200 \%(\mathrm{v} / \mathrm{v})$, however, all essential oils exhibited strong cytotoxicities towards PC-3 cells. Cell viability was lower than 4\%. Most essential oils exhibited strong cytotoxicities towards A549 cells. However, cells treated with mint essential oil still grew well, and the number of survival cells was comparable to that of untreated control cells. For MCF-7 cell, the cytotoxictiies of cinnamon, thyme, chamomile, and jasmine essential oils was significantly stronger than that of the other six essential oils. The fractions of viable cells were reduced to $5.31 \%, 3.47 \%$, $6.93 \%$ and $4.34 \%$, respectively. Essential oils from grapefruit and ginger exhibited the lowest 
cytotoxicities towards MCF-7 cells. The percentages of cells viability were $75.03 \%$ and $81.85 \%$, respectively.

Of all essential oils investigated, thyme essential oil exhibited the strongest cytotoxicities towards cancer cells. The $\mathrm{IC}_{50}$ values for thyme essential oil against PC-3, A549 and MCF-7 cells were $0.010 \%, 0.011 \%$ and $0.030 \%(\mathrm{v} / \mathrm{v})$, respectively. Moreover, cinnamon and jasmine essential oils possessed stronger cytotoxic activities towards PC-3 and A549 cell lines. IC $_{50}$ values for cinnamon essential oil against PC-3 and A549 cells were $0.012 \%(\mathrm{v} / \mathrm{v})$ and $0.017 \%(\mathrm{v} / \mathrm{v})$. The $\mathrm{IC}_{50}$ values for jasmine essential oil against these two cell lines were $0.022 \%(\mathrm{v} / \mathrm{v})$ and $0.012 \%(\mathrm{v} / \mathrm{v})$ respectively. However, the $\mathrm{IC}_{50}$ values for cinnamon and jasmine essential oils against MCF-7 cells were 0.076\% $(\mathrm{v} / \mathrm{v})$ and $0.077 \%(\mathrm{v} / \mathrm{v})$. MCF-7 cell was less sensitive than the other cell lines towards the essential oils.

Figure 3. Dose-dependent cytotoxicity of 10 essential oils (72 h exposure) towards PC-3 (A), A549 (B) and MCF-7 (C) cell lines as determined by the MTT assay. Values are expressed as means \pm SD of three independent experiments. Standard deviations were less than $15 \%$.
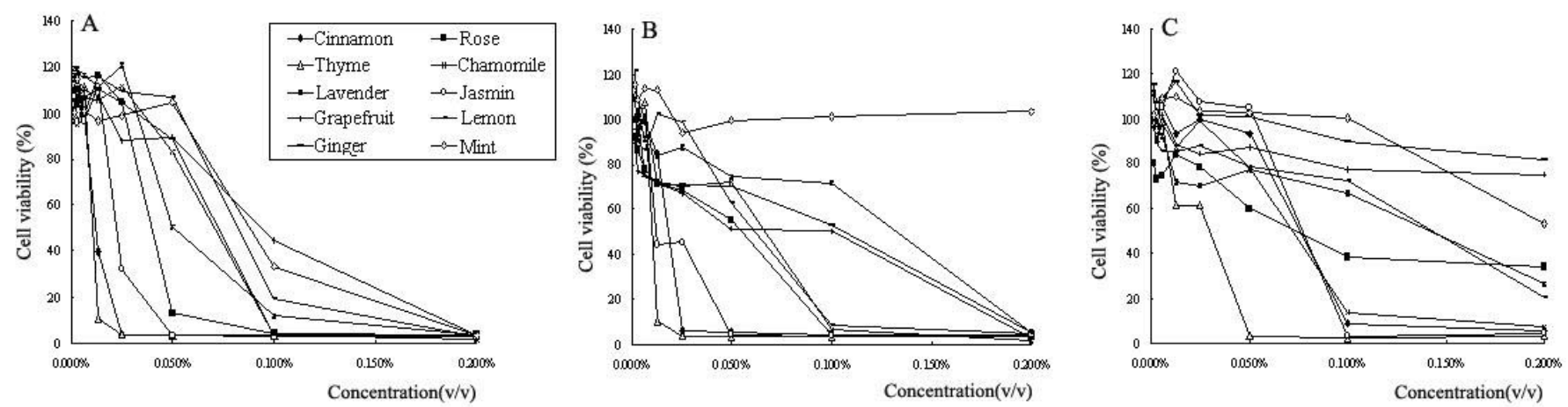

Table 2. Inhibition concentrations $50 \%\left(\mathrm{IC}_{50}, \% \mathrm{v} / \mathrm{v}\right)$ values for 10 essential oils of PC-3, A549 and MCF-7 cancer cell lines as determined by the MTT assay.

\begin{tabular}{ccccccccccc}
\hline & cinnamon & rose & thyme & chamomile & lavender & jasmine & grapefruit & lemon & ginger & mint \\
\hline PC-3 & 0.012 & 0.040 & 0.010 & 0.071 & 0.050 & 0.022 & 0.094 & 0.083 & 0.077 & 0.088 \\
A549 & 0.017 & 0.055 & 0.011 & 0.067 & 0.133 & 0.012 & 0.100 & 0.061 & 0.107 & ------ \\
MCF-7 & 0.076 & 0.074 & 0.030 & 0.072 & 0.142 & 0.077 & ------ & 0.143 & ------ & ------ \\
\hline
\end{tabular}

Anti-bacterial and cytotoxic activities of essential oils can be attributed to their different constituents. Essential oils comprise complex mixtures, including monoterpenes and sesquiterpenes, such as limonene, menthol, $\alpha$-pinene, 3 -carene, and $\alpha$-farnesol, etc. Some compositions have been reported for their anti-bacterial activities towards bacteria and fungi [21,22]. The anti-cancer activities of some monoterpenes and sesquiterpenes was also reported in the literature [23,24].

Until now, various authors have reported antitumor activities of essential oils as well as their components. For instance, the lavender essential oil was found to be active against COL-2 [25], the aldehyde compounds of Citrus paradisi essential oil induced apoptosis strongly in HL-60 cells [26], and thyme essential oil, which contains carvacrol, as the major component has an important in vitro cytotoxic activity against tumor cells [27]. In our results, ten essential oils (except for grapefruit, 
ginger and mint) also showed excellent antitumor activities against PC-3, A549, MCF-7. However, further studies are urgently needed for screening for the mechanism of the antitumor activity.

\section{Experimental}

\subsection{Essential oils}

Essential oils of mint (Mentha spicata), ginger (Zingiber officinale), lemon (Citrus limonum), grapefruit (Citrus paradisi), jasmine (Jasminum grandiflora), lavender (Lavandula stoechas), chamomile (Anthemis nobilis), thyme (Thymus vulgaris), rose (Rosa centifolia) and cinnamon (Cinnamomum zeylanicum) were obtained from a commercial source (Xiamen Denyla Essential Ooil Co., Ltd., Xiamen, China).

\subsection{Maintenance of Proprionibacterium acnes}

P. acnes (CMCC 65002) was purchased from China General Microbiological Culture Collection Center (CGMCC, Beijing, China). The organism was incubated in brain heart infusion medium (BHI) with $1 \%$ glucose (Aoboxing Biotech Company Ltd., Bejing, China) at $37{ }^{\circ} \mathrm{C}$ for $72 \mathrm{~h}$ under anaerobic conditions and adjusted concentration by direct microscopic counts before the assay.

\subsection{Disc diffusion assay}

The determination of inhibition diameters of $P$. acnes colonies by essential oils was carried out by the agar disc diffusion method [28]. The BHI agar media plate was swabbed with the bacterial suspension $\left(10^{8} \mathrm{CFU} / \mathrm{mL}\right)$ and kept for $30 \mathrm{~min}$ at $4{ }^{\circ} \mathrm{C}$. Filter paper discs $(6.0 \mathrm{~mm}$ in diameter) were soaked with $5 \mu \mathrm{L}$ essential oil and placed on the surface of the inoculated BHI agar plates. Plates were incubated under anaerobic condition at $37{ }^{\circ} \mathrm{C}$ for $24 \mathrm{~h}$. Three independent experiments were performed, and the diameters were recorded as mean values.

\subsection{Determinition of MICs and MBCs values}

The MIC (minimal inhibitory concentration) and MBC (minimal bactericidal concentration) tests were performed by the broth microdilution method [29]. The essential oils were dissolved in sterilized physiological saline solution (0.9\%) supplemented with Tween-80 (Sigma) at final concentration of $0.5 \%(\mathrm{v} / \mathrm{v})$. Serial two-fold dilutions from $1.000 \%-0.008 \%(\mathrm{v} / \mathrm{v})$ of the essential oils were prepared and placed into a 96-well micro-titer plate. One hundred $\mu \mathrm{L}$ of sample of each concentration were dispensed into the wells of a micro-titer plate. Each well was then inoculated with $100 \mu \mathrm{L}$ of the bacterial suspension. The final concentration of the suspension was adjusted to $10^{5} \mathrm{CFU} / \mathrm{mL}$, and the plate was incubated under anaerobic condition at $37{ }^{\circ} \mathrm{C}$ for $24 \mathrm{~h}$. After incubation, the wells were examined for growth of microorganisms and the MIC was determined. The MIC is defined as the lowest concentration of the essential oil at which the bacterium does not demonstrate visible growth. MBC was confirmed by reinoculating on agar plates with $10 \mu \mathrm{L}$ of each culture medium from the microplates. The number of $\mathrm{CFU} / \mathrm{mL}$ was determined after $24 \mathrm{~h}$ of incubation at $37{ }^{\circ} \mathrm{C}$. $\mathrm{MBC}$ is 
defined as the lowest concentration of the essential oil at which incubated microorganisms are completely killed. Each experiment was repeated three times.

\subsection{Time-kill dynamic curves}

Time-kill dynamic procedures were performed as described by Avila et al. [30] with minor modifications. The final concentration of suspension of the strain was adjusted to $10^{5}-10^{6} \mathrm{CFU} / \mathrm{mL}$. According to the results of MIC and MBC of 10 essential oils, the $0.25 \%(\mathrm{v} / \mathrm{v})$ concentration of each essential oil was selected for use in the time-kill dynamic procedure. After incubating for $0,5,10,20$, $30,45,60,90$ and $120 \mathrm{~min}$. with the broth micro dilution method, liquids $(50 \mu \mathrm{L})$ were removed from the test solution for ten-fold serial dilution. Thereafter, a $25 \mu \mathrm{L}$ liquid from each dilution was spread on the surface of the BHI agar plates and incubated at $37{ }^{\circ} \mathrm{C}$ under anaerobic condition for $24 \mathrm{~h}$, and the number of $\mathrm{CFU} / \mathrm{mL}$ was counted. The solution with no essential oil was used as a control. Experiments were carried out in triplicate. Time-kill curves were constructed by plotting the number of $\mathrm{CFU} / \mathrm{mL}$ against time (min).

\subsection{Maintenance of human cancer cell lines}

Human lung carcinoma (A549), human prostate carcinoma (PC-3) and human breast cancer cell lines (MCF-7) were purchased from China Center for Type Culture Collection (Wuhan, China). These cell lines were grown and maintained in a humidified incubator at $37^{\circ} \mathrm{C}$ with a $5 \% \mathrm{CO}_{2}$ atmosphere. Dulbecco's modified Eagle's medium (DMEM) supplemented with 10\% fetal bovine serum (FBS), $100 \mathrm{U} / \mathrm{mL}$ penicillin and $100 \mu \mathrm{g} / \mathrm{mL}$ streptomycin was used for the A549 cell cultures. Roswell Park Memorial Institute Medium (RPMI) 1640 medium supplemented with 10\% FBS, $100 \mathrm{U} / \mathrm{mL}$ penicillin and $100 \mu \mathrm{g} / \mathrm{mL}$ streptomycin was used as the culture medium for PC-3 and MCF-7 cells.

\subsection{Cytotoxicity assay}

The cytotoxic effects of the essential oils on three human tumor cell lines were assayed by the MTT assay [31]. The cells were seeded at a density of $5 \times 10^{4}$ cells/well. The 10 essential oils were serially double diluted from $0.200 \%$ to $0.002 \%(\mathrm{v} / \mathrm{v})$, and $100 \mu$ liquid of each concentration was applied to the wells of a 96-well plate containing confluent cell monolayers (six wells per concentration). The dilution medium without the sample served as a control. After $72 \mathrm{~h}$ of incubation, MTT solution $(5 \mathrm{mg} / \mathrm{mL}$ ) was then added to each well. and the formazan precipitate was dissolved in $100 \mu \mathrm{L}$ dimethyl sulfoxide after $4 \mathrm{~h}$ incubation, After shaking for $5 \mathrm{~min}$, the content of the wells was homogenized on a microplate shaker. The optical densities (OD) were measured on a microplate ELISA reader at $570 \mathrm{~nm}$. All tests and analyses were run in triplicate and mean values were recorded. The cell survival curves were calculated after comparing with the control. The percentage viability was calculated as follows:

$$
\% \text { viability }=\frac{\text { mean absorbance of treated wells }}{\text { mean absorbance of control wells (no oil) }} \times 100
$$




\section{Conclusions}

Among the 10 essential oils investigated in the present study, thyme and cinnamon essential oils exhibited the strongest anti-bacterial activities towards P. acnes and cytotoxic activities towards A549, PC-3, and MCF-7 human tumor cell lines. The main components of thyme essential oil is thymol [32], whose anti-microbial activities have been previously reported [33]. Its mechanism of action towards $S$. aureus and E. coli was also reported [34]. The main component of cinnamon is eugenol [35], which possesses notable anti-bacterial and anti-oxidant effects [36]. It was also found to be a potent inhibitor of melanoma cell proliferation [37]. We hypothesize that these two constituents may also be responsible for the antibacterial and cytotoxic activities of thyme or cinnamon essential oil observed in this investigation. Other essential oils also comprise monoterpenes, such as limonene and menthol, that possess bioactivity. On the basis of our results, 10 ten essential oils analyzed in this study may be used as alternative for food, cosmetics and medicine. In addition to their use for food and cosmetics, the potential of essential oils for the treatment of acne and cancer merits further exploration in the future.

\section{Acknowledgements}

The authors gratefully acknowledge the financial supports by National Natural Science Foundation of China (30770231), Heilongjiang Province Science Foundation for Excellent Youths (JC200704), Agricultural Science and Technology Achievements Transformation Fund Program (2009GB23600514), Key Project of Chinese Ministry of Education (108049), National Key Technology R \& D Program (2006BAD18B0405), Innovative Program for Importation of International Advanced Agricultural Science and Technology, National Forestry Bureau (2006-4-75), Key Program for Science and Technology Development of Harbin (2009AA3BS083), Research Foundation for Science, Technology Innovation Talents of Harbin (2006RFXXS001) and Fundamental Research Funds for the Central Universities (DL09EA04).

\section{References and Notes}

1. Buckle, J. Use of aromatherapy as a complementary treatment for chronic pain. Altern Ther Health Med. 1999, 5, 42-51.

2. Sylvestre, M.; Pichette, A.; Longtin, A.; Nagau, F.; Legault, J. Essential oil analysis and anticancer activity of leaf essential oil of Croton flavens L. from Guadeloupe. J. Ethnopharmacol. 2006, 103, 99-102.

3. Mimica-Dukic, N.; Bozin, B.; Sokovic, M.; Simin, N. Antimicrobial and antioxidant activities of Melissa officinalis L. (Lamiaceae) essential oil. J. Agric. Food. Chem. 2004, 52, 2485-2489.

4. Sylvestre, M.; Legault, J.; Dufour, D.; Pichette, A. Chemical composition and anticancer activity of leaf essential oil of Myrica gale L. Phytomedicine 2005, 12, 299-304.

5. Park, J.; Lee, J.; Jung, E.; Park, Y.; Kim, K.; Park, B.; Jung, K.; Park, E.; Kim, J.; Park, D. In vitro antibacterial and anti-inflammatory effects of honokiol and magnolol against Propionibacterium sp. Eur. J. Pharmacol. 2004, 496, 189-195.

6. Jappe, U. Pathological mechanisms of acne with special emphasis on Propionibacterium acnes and related therapy. Acta Derm. Venereo. 2003, 83, 241-248. 
7. Poulin, Y. Practical approach to the hormonal treatment of acne. J. Cutan. Med. Surg. 2004, 4, 6-21.

8. Tan, A.W.; Tan, H.H. Acne vulgaris: a review of antibiotic therapy. Expert Opin. Pharmacother. 2005, 6, 409-418.

9. Leyden, J.J. Antibiotic resistance in the topical treatment of acne vulgaris. Cutis 2004, 73, 6-10.

10. Yemisci, A.; Gorgulu, A.; Piskin, S. Effects and side-effects of spironolactone therapy in women with acne. J. Eur. Acad. Dermatol. Venereol. 2005, 19, 163-166.

11. Lertsatitthanakorn, P.; Taweechaisupapong, S.; Aromdee, C.; Khunkitti, W. In vitro bioactivities of essential oils used for acne control. Int. J. Astrobiol. 2006, 16, 43-49.

12. Efferth, T.; Fu, Y.J.; Zu, Y.G.; Schwarz, G.; Konkimall, V.S. Wink, M. Molecular target-guided tumor therapy with natural products derived from traditional Chinese medicine. Curr. Med. Chem. 2007, 14, 2024-2032.

13. Lai, P.K.; Roy, J. Antimicrobial and chemopreventive properties of herbs and spices. Curr. Med. Chem. 2004, 11, 1451-1460.

14. Soković, M.D.; Vukojević, J.; Marin, P.D.; Brkić, D.D.; Vajs, V.; van Griensven, L.J. Chemical composition of essential oils of Thymus and Mentha species and their antifungal activities. Molecules 2009, 14, 238-249.

15. Sabulal, B.; Dan, M.; J.A.J.; Kurup, R.; Pradeep, N.S.; Valsamma, R.K.; George, V. Caryophyllene-rich rhizome oil of Zingiber nimmonii from South India: Chemical characterization and antimicrobial activity. Phytochemistry 2006, 67, 2469-2473.

16. Ganzera, M.; Schneider, P.; Stuppner, H. Inhibitory effects of the essential oil of chamomile (Matricaria recutita L.) and its major constituents on human cytochrome P450 enzymes. Life Sci. 2006, 78, 856-861.

17. Shen, J.; Niijima, A.; Tanida, M.; Horii, Y.; Nakamura, T.; Nagai, K. Mechanism of changes induced in plasma glycerol by scent stimulation with grapefruit and lavender essential oils. Neurosci. Lett. 2007, 416, 241-246.

18. Hamdan, D.; El-Readi, M.Z.; Nibret, E.; Sporer, F.; Farrag, N.; El-Shazly, A.; Wink, M. Chemical composition of the essential oils of two Citrus species and their biological activities. Pharmazie 2010, 65, 141-147.

19. Lauriola, M.M.; De Bitonto, A.; Sena, P. Allergic contact dermatitis due to cinnamon oil in galenic vaginal suppositories. Acta Derm. Venereol. 2010, 90, 187-188.

20. Wei, A.; Shibamoto, T. Antioxidant activities and volatile constituents of various essential oils. J. Agric. Food Chem. 2007, 55, 1737-1742.

21. Mourey, A.; Canillac, N. Anti-Listeria monocytogenes activity of essential oils components of conifers. Food Contr. 2002, 13, 289-292.

22. Oumzil, H.; Ghoulami, S.; Rhajaoui, M.; Ilidrissi, A.; Fkih-Tetouani, S.; Faid, M.; Benjouad, A. Antibacterial and antifungal activity of essential oils of Mentha suaveolens. Phytother. Res. 2002, $16,727-731$.

23. Legault, J.; Dahl, W.; Debiton, E.; Pichette, A.; Madelmont, J.C. Antitumor activity of balsam fir oil: production of reactive oxygen species induced by alpha-humulene as possible mechanism of action. Planta Med. 2003, 69, 402-407. 
24. Wiseman, D.A.; Werner, S.R.; Crowell, P.L. Cell cycle arrest by the isoprenoids perillyl alcohol, geraniol, and farnesol is mediated by p21 (Cip1) and p27 (Kip1) in human pancreatic adenocarcinoma cells. J. Pharmacol. Exp. Ther. 2007, 320, 1163-1170.

25. Gören, A.; Topçu, G.; Bilsel, G.; Bilsel, M.; Aydoğmuş, Z.; Pezzuto, J.M. The chemical constituents and biological activity of essential oil of Lavandula stoechas ssp. stoechas. Z. Naturforsch C. 2002, 57, 797-800.

26. Hata, T.; Sakaguchi, I.; Mori, M.; Ikeda, N.; Kato, Y.; Minamino, M.; Watabe, K. Induction of apoptosis by Citrus paradisi essential oil in human leukemic (HL-60) cells. In Vivo 2003, 17, 553-559.

27. Ait M'barek, L.; Ait Mouse, H.; Jaâfari, A.; Aboufatima, R.; Benharref, A.; Kamal, M.; Bénard. J.; El Abbadi, N.; Bensalah, M.; Gamouh, A.; Chait, A.; Dalal, A.; Zyad, A. Cytotoxic effect of essential oil of thyme (Thymus broussonettii) on the IGR-OV1 tumor cells resistant to chemotherapy. Braz. J. Med. Biol. Res. 2007, 40, 1537-1544.

28. Hernández, T.; Canales, M.; Avila, J.G.; García, A.M.; Martínez, A.; Caballero, J.; de Vivar, A.R.; Lira, R. Composition and antibacterial activity of essential oil of Lantana achyranthifolia Desf. (Verbenaceae). J. Ethnopharmacol. 2005, 96, 551-554.

29. Yu, J.Q.; Lei, J.C.; Yu, H.D.; Cai, X.; Zou, G.L. Chemical composition and antimicrobial activity of the essential oil of Scutellaria barbata. Phytochemistry. 2004, 65, 881-884.

30. Avila, J.G.; de Liverant, J.G.; Martínez, A.; Martínez, G.; Muñoz, J.L.; Arciniegas, A.; de Vivar, A.R. Mode of action of Buddleja cordata verbascoside against Staphylococcus aureus. J. Ethnopharmacol. 1999, 66, 75-78.

31. Mosmann, T. Rapid colorimetric assay for cellular growth and survival: application to proliferation and cytotoxicity assays. J. Immunol. Meth. 1983, 65, 55-63.

32. Tomaino, A.; Cimino, F.; Zimbalatti, V.; Venuti, V.; Sulfaro, V.; De Pasquale, A.; Influence of heating on antioxidant activity and the chemical composition of some spice essential oils. Food Chem. 2005, 89, 549-554.

33. Falcone, P.M.; Mastromatteo, M.; Del Nobile, M.A.; Corbo, M.R.; Sinigaglia, M. Evaluating in vitro antimicrobial activity of thymol toward hygiene-indicating and pathogenic bacteria. J. Food Prot. 2007, 70, 425-431.

34. Trombetta, D.; Castelli, F.; Sarpietro, M.G.; Venuti, V.; Cristani, M.; Daniele, C.; Saija, A.; Mazzanti, G.; Bisignano, G. Mechanisms of antibacterial action of three monoterpenes. Antimicrob. Agents Chemother. 2005, 49, 2474-2478.

35. Singh, G.; Maurya, S.; DeLampasona, M.P.; Catalan, C.A. A comparison of chemical, antioxidant and antimicrobial studies of cinnamon leaf and bark volatile oils, oleoresins and their constituents. Food Chem. Toxicol. 2007, 45, 1650-1661.

36. Chami, N.; Bennis, S.; Chami, F.; Aboussekhra, A.; Remmal, A. Study of anticandidal activity of carvacrol and eugenol in vitro and in vivo. Oral Microbiol. Immunol. 2005, 20, 106-111. 
37. Ghosh, R.; Nadiminty, N.; Fitzpatrick, J.E.; Alworth, W.L.; Slaga, T.J.; Kumar, A.P. Eugenol causes melanoma growth suppression through inhibition of E2F1 transcriptional activity. J. Biol. Chem. 2005, 280, 5812-5819.

Sample Availability: Samples of the compounds are available from the authors.

(C) 2010 by the authors; licensee MDPI, Basel, Switzerland. This article is an open-access article distributed under the terms and conditions of the Creative Commons Attribution license (http://creativecommons.org/licenses/by/3.0/). 